\title{
Development of a Measurement Tool for Sustainable Development
}

\section{Awareness}

\author{
Ayşe Ceren Atmaca ${ }^{1}$, Seyit Ahmet Kiray (iD), ${ }^{*}$, Mustafa Pehlivan ${ }^{1}$
}

\author{
${ }^{1}$ Necmettin Erbakan University, Ahmet Kelesoglu Education Faculty, Department of Mathematics and Science \\ Education, Division of Science Education, Konya/Turkey
}

\section{ARTICLE HISTORY}

Received: 07 September 2018

Revised: 26 December 2018

Accepted: 18 January 2019

\section{KEYWORDS}

Sustainability,

Sustainable development,

Sustainable development awareness

\begin{abstract}
Raising the sustainable development awareness is of great importance for the continuation of the world's livability. Teachers have a great responsibility in order for individuals to make sustainable development a part of their lives. For this reason, teachers need to be individuals with sustainable development awareness. In this study, it was aimed to develop a scale for determining the sustainable development awareness of teacher candidates. The developed scale consists of three subdimensions including economy, society, and environment and a total of 36 items. 425 science teacher candidates from seven state universities in Turkey participated in the research. The Cronbach's alpha reliability coefficient for the overall scale was calculated as 0.91 . Confirmatory factor analysis was performed for the validity of the scale. In light of the analyses, the scale was found to possess the qualifications to determine the sustainable development awareness of science teacher candidates.
\end{abstract}

\section{INTRODUCTION}

Industrialization in the 20th century with the destruction of the environment caused by the unconscious steps taken in the name of development under the influence of rapid population growth together with urbanization brought concerns about human health and the future of the world (Altunbaş, 2003). In the aftermath of the destruction of natural life and the unconscious use of resources, many parts of the world have begun to suffer from food and water scarcity and, consequently, many deadly problems such as hunger, diseases, and poverty. In addition, climate change and global warming have become the most important issues affecting the future of our planet (Yerdelen, Cansiz, Cansiz, \& Akcay, 2018). It has been noticed by all the communities that the Earth's self-renewal capacity is severely damaged. It has been understood that in the continuation of this course, the Earth will lose its ability to become a livable planet. Noticing that these problems will threaten not just a certain region but the whole world if not taken care of has led the search of solutions in the global scale (Baykal \& Baykal, 2008). It has been decided that sustainable development should be included in education programs by

CONTACT: Seyit Ahmet Kiray $₫$ ahmetkiray@gmail.com $\equiv$ Necmettin Erbakan University, Ahmet Kelesoglu Education Faculty, Department of Mathematics and Science Education, Division of Science Education, Konya/Turkey 
understanding that these problems can be solved only if every individual, every society, and every state living on the Earth are able to work together in collaboration and take certain responsibilities (Biasutti \& Frate, 2017; Erten, 2015).

\subsection{Sustainable Development}

Sustainable development was first officially discussed in the Brundtland Report published by the World Commission on Environment and Development in 1987, and the corresponding rapporteur defined it as "sustainable development that meets the needs of the present generation without compromising the ability of future generations to meet their own needs" (WCED, 1987). When looking at the definitions of sustainable development, international texts and sustainable development approaches, it is seen that sustainable development has three dimensions, namely economy, environment, and society (Borg, Gericke, Höglund, \& Bergman, 2012; Olsson, Gericke, \& Chang Rundgren, 2016). In order for sustainable development to take place, the sustainability of these three dimensions must be ensured simultaneously (Alkış, 2007; Sandel, Öhman, \& Östman, 2006).

The society dimension of sustainable development includes the concepts of human rights, gender equity, peace and human security, cultural diversity and inter-cultural understanding (UNESCO, 2006), social services, health and education right, and social justice (Atmaca, Kiray, \& Pehlivan, 2018; Özmete \& Akgul-Gök, 2015).

Environmental sustainability includes issues such as the protection of natural resources (water, air, soil, energy, agriculture, and biodiversity), sustainable urbanization (UNESCO, 2006), reduction of environmental pollution (water, air, soil pollution), the use of renewable energy sources (geothermal, wind energy, etc.) instead of non-renewable energy sources (coal, petrol, etc.), protection of forests and increasing green areas, reduction of resource usage and environmental pollution by recycling of wastes, ecological footprint minimization, and stopping the global warming (Atmaca, et al., 2018; Koçak \& Balc1, 2010).

Economic sustainability, on the other hand, includes issues such as conservative use of resources, income and expense balance, elimination of income distribution inequality, sustainable production and cost, reliable environments for investments, investments in highincome sectors, investments in vital sectors, and research and development (Atmaca, et al., 2018; Kuşat, 2013; Olsson, Gericke, \& Chang Runghen, 2016; Şahin \& Kutlu, 2014).

\subsection{Scale Development Studies on Sustainable Development}

Türer (2010) developed the Sustainable Development Awareness Questionnaire as a measurement tool in his study that aimed to determine sustainable development awareness of social science and science teacher candidates. The questionnaire, developed by the researcher, consists of 3 sub-dimensions including social, economic and environmental in accordance with the theoretical framework of sustainable development in the literature and consists of 21 items. Chow and Chen (2012) developed a corporate sustainable development scale to determine how well the management strategies of companies overlap with the sustainable development contexts. Similar to Türer's study, the developed scale consists of 22 items that are prepared for social, economic, and environmental sustainability contents frequently encountered as dimensions of sustainable development in the literature. The 'Survey of Education for Sustainable Development Competencies (SSESDC)' that was used by Biasutti and Surian (2012) in their study in order to investigate sustainable development competence areas of students from different universities was developed by a research team led by Professor Vassilios Makrakis in the RUCAS Tempus project. The survey includes an education dimension in addition to the environmental, economic and social dimensions that are frequently encountered as dimensions of sustainable development in the literature. The educational dimension includes 
items in areas such as the attitudes towards sustainable development education, learning to exist, learning to live together in a sustainable way, learning to know, learning to do, learning to improve oneself and society. Biasutti and Frate (2017) developed a scale to be used to determine students' attitudes towards sustainable development in their study. The scale includes three dimensions (economy, society, environment) that are common in the literature, such as the measure developed by Biasutti and Surian (2012), with an addition of the educational dimension. In the dimension of education on the scale, areas such as student-centered teaching methods, future-oriented thinking, higher-order thinking skills, critical thinking, interdisciplinary, and related global and local subjects were emphasized. The sustainable development attitude scale developed after the validity and reliability analyzes was finalized with 4 sub-dimensions and 20 items. Kaya (2013) also developed a sustainable development attitude scale with the aim of determining the attitudes of secondary school students towards sustainable development. The developed scale consists of 3 sub-dimensions including social, environmental and economical and has 21 items in total. Similar to Biasutti and Frate's (2017) study, Manju (2015) developed a survey to investigate the views of teachers on the role of education in sustainable development. The developed questionnaire consists of 25 items focusing on sustainable development and its relationship to education. Unlike other studies, Doğan, Bulut ve Çımrın (2015) focused on sustainable consumption behaviors. Doğan, Bulut and Çımrın (2015) developed Sustainable Consumption Behavior Scale, which consists of 20 items, in their study that aimed to develop a scale for measuring sustainable consumption behaviors. The scale has four factors as environmental awareness, unnecessary purchase, saving, and reusability.

\subsection{The Importance of Research}

The only way for sustainable development activities to reach its goal and become a way of life is to raise individuals who have sustainable development awareness and who shape their lives in the direction of sustainable development principles. The only way to raise individuals with sustainable development awareness is education (Aydoğan, 2010). Education is at the center of sustainable development. However, it is not meant to be an educational information accumulation. Education for sustainable development is aimed at educating individuals in accordance with sustainable development principles such as knowledge, attitudes, values, and behavior through a program that includes environmental, economic, and social issues (Summers, Kruger, Childs, \& Mant, 2010).

If individuals are meant to be educated with sustainable development awareness, educators in all branches should be individuals with sustainable development awareness. In order for the education process to be carried out in an appropriate and productive way, it is necessary for teachers to have an awareness of their field and therefore to have sufficient knowledge, skills, values, and attitudes regarding that field. In this context, in order to educate individuals who have sustainable development awareness, teacher candidates who chose teaching as a profession and have been trained in education faculties should begin this profession as individuals with sustainable development awareness once they graduate (Demirbaş, 2015; Kahyaoğlu 2011).

Science teachers, one of the lessons expected to bring sustainable development skills to individuals, has a vital role. Science teachers need to be educators who have awareness of sustainable development in order to give students the objectives that will provide the opportunity to make sustainable development a way of life by teaching science lesson appropriately for its purpose. It is expected that today's science teacher candidates who will be future science teachers will have sustainable development awareness. This research is a scale development study designed to determine the sustainable development awareness levels of 
science teacher candidates. When the scales containing the economic, social, and environmental dimensions in the literature are examined, it can be seen that the items of the economy and the society dimensions are different while the scales have almost similar properties in the items of the environmental dimension. This scale differs from other studies especially in terms of the approach to these two dimensions. Studies in the literature often have small number of items, which reduce the content validity of sustainable development sub-dimensions. In this study, a scale was developed which has almost twice the number of items in the other studies, in which the content determined with the help of the literature and experts' opinions was fully reflected to the scale items. That is why this scale also has a more inclusive feature than other scale development studies.

\section{METHODS}

In this study, the validity and reliability analyses of the sustainable development awareness scale developed for science teacher candidates were conducted.

\subsection{Study Group}

Sustainable Development Awareness Scale developed in the study was given to 425 science teacher candidates who were senior students at seven different universities in Turkey during the 2017-2018 academic year. The Departments of Science Education in Turkey are divided into three groups as lower, middle, and upper according to the university entrance scores. To apply the scale, the universities have been determined by choosing approximately the same number of pre-service teachers from these three groups such as 2 from the upper group, 2 from the middle group, and 3 from the lower group. The teacher candidates participating in the survey were given 20 minutes to answer the whole scale. Of the 425 science teachers who participated in the research, $340(80 \%)$ were female and $85(20 \%)$ were male.

\subsection{Data Collection Tool Development Process}

At the first step in the scale development process, the literature on sustainable development was searched. As a result of the literature review, 54 items were written based on the content of the economic, environmental, and social dimensions, which are three sub-dimensions of sustainable development. Considering the opinions of four experts from different universities, the prepared item pool was re-examined by the researchers and the items that measure same features were eliminated. A final draft of 36 items was drawn up. When the sustainable development scale is divided into sub-dimensions, it is noticed that some items can be included in more than one sub-dimension. For example, item number 21 (Urbanization should be to protect the soul and body health of the society) has a characteristic that can be included in both the society and the environment sub-dimension. When deciding on to which sub-dimension such items should be included, the question of which characteristic of these items are more dominant was directed to three external experts. The item number 21 has been included in the social dimension because its social characteristic is more dominant and expert views were in this direction. Expert opinions were used to include items that correspond to regions where subdimensions show intersecting features. For the final form of the scale, expert views were consulted once again. The necessary revisions were made in line with the expert feedback and the scale was prepared for implementation. The draft form prepared to determine the Sustainable Development Awareness of the teacher candidates was prepared in the 5-point Likert type. In the corresponding columns of the items prepared to identify the sustainable development awareness of the teacher candidates, rating statements such as strongly disagree, disagree, neutral, agree, strongly agree were placed. The revised form of the scale was applied to the two teacher candidates at the fourth grade level in the Department of Science Education. With this application, feedback on readability and comprehensibility was provided and the 
recommended time for the scale was determined. The scale was applied to 425 science teacher candidates. Confirmatory factor analysis was preferred for construct validity of the scale. Reliability analyses of the scale were performed in the SPSS package program.

\section{RESULTS and DISCUSSION}

In this section, data on the validity and reliability analyses of the scale obtained in the scale development process are presented.

\subsection{Validity Analysis of the Scale}

Content validity of the scale was provided by expert opinion and construct validity by confirmatory factor analysis.

\subsection{Content Validity}

For the sustainable development awareness scale, the literature was searched by the researchers and a pool of items containing 54 statements was created. The 54 items were re-examined by the researchers and the items measuring the same features were eliminated. As a result of the examination, a draft form was created with 36 items decided by the researchers. The 36 items that have been decided on include awareness about the sustainability practices regarding the three dimensions of sustainable development, namely economy, society, and environment, which are the three sub-dimensions in the literature. For the expert view, the draft form was sent to four faculty members who are in science education department of three different state universities in Turkey. In accordance with the feedback obtained from experts, the necessary revisions were made in scale items.

\subsection{Construct validity}

Factor analysis was carried out in order to determine the construct validity of the scale developed for the determination of sustainable development awareness of science teacher candidates. Confirmatory factor analysis may be preferred for construct validity when the theoretical structure is evident (Akcay, Gelen, Tiryaki, \& Benek, 2018; De Vellis, 2012).

In this study, construct validity was provided by confirmatory factor analysis, as scale items were prepared based on the contents of economy, environment, and society dimensions, which are three sub-dimensions of sustainable development in the literature. Confirmatory factor analysis with the aim of providing the construct validity of the Sustainable Development Awareness Scale prepared with three sub-dimensions according to theoretical framework was carried out on the AMOS program. As the multivariate normality assumption was fulfilled, the Maximum Likelihood (MLR) estimation method was used for the models.

For the confirmatory factor analysis in the study, $x^{2} / d f$ (value obtained by dividing the Chisquare fit statistic by the degree of freedom), RMSEA (Root Mean Square Error of Approximation), S-RMR (Standardized Root Mean Square Residual), AGFI (Adjusted Goodness of Fit Index), GFI (Goodness of Fit Index), IFI (Incremental Fit Index), and TLI (Trucker Lewis Index) were examined. In the confirmatory factor analysis, the fit indices used to determine whether the theoretical framework supports the data are given in Table 1 (Hebebci, \& Shelley, 2018; Kline, 2005; Tabachnick \& Fidell, 2007). The values obtained when the analysis is repeated after the modification between the specified items as a result of the preliminary analysis were calculated as $x^{2}=964.497, d f=575, p=.000, x^{2} / d f=1.677$, RMSEA $=0.40, \mathrm{~S}-\mathrm{RMR}=0.44, \mathrm{AGFI}=.871, \mathrm{GFI}=.889, \mathrm{IFI}=.931, \mathrm{TLI}=.923$ (Table 1$).$ When the values were evaluated on the basis of the fit indices, $x^{2} / d f$, RMSEA, and S-RMR values were found to be in perfect fit. GFI, AGFI, IFI, and TLI values were found to be in the acceptable range. Thus, the construct of the scale is valid. The path diagram for the confirmatory factor model of the Sustainable Development Awareness Scale is shown in Figure 1. 


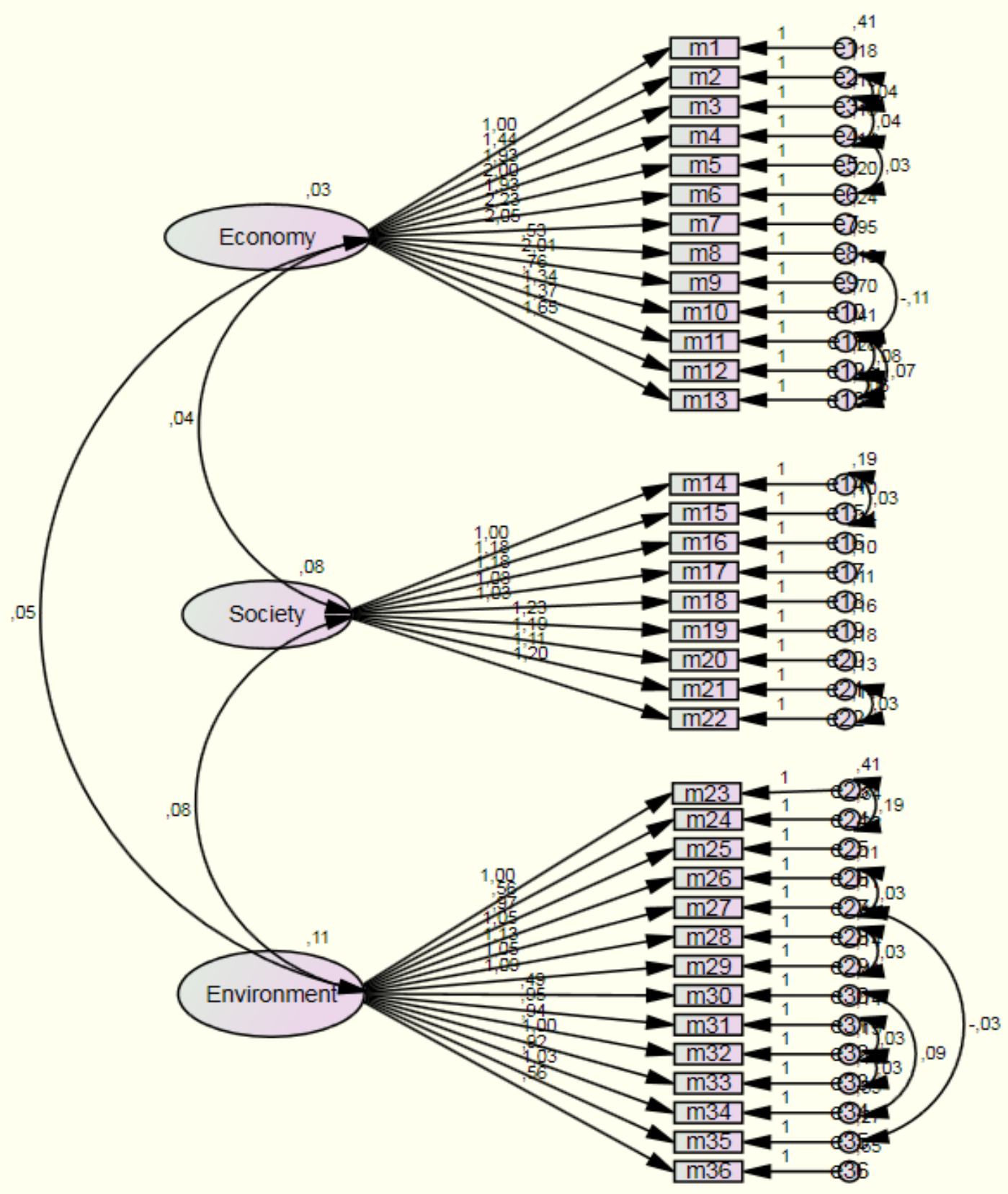

Figure 1. The path diagram for confirmatory factor model of Sustainable Development Awareness Scale

Table 1. Confirmatory Factor Model Fit Indices of Sustainable Development Awareness Scale After Modifications

\begin{tabular}{llll}
\hline Fit Indices & Perfect Fit & Acceptable Fit & Fit Indices Observed in Scale Model \\
\hline$x^{2} / d f$ & $x^{2} / d f \leq 3$ & $3<x^{2} / d f<5$ & 1.67 \\
\hline RMSEA & $0<$ RMSEA $\leq 0.05$ & $0.06<$ RMSEA $<0.08$ & .040 \\
\hline S-RMR & $0 \leq \mathrm{S}-\mathrm{RMR} \leq 0.05$ & $0.05<\mathrm{S}$-RMR $<0.10$ & .044 \\
\hline GFI & GFI $\geq 0.90$ & $0.85<\mathrm{GFI}<0.90$ & .889 \\
\hline AGFI & AGFI $\geq 0.90$ & $0.85<\mathrm{AGFI}<0.90$ & .871 \\
\hline IFI & IFI $\geq 0.95$ & $0.90<\mathrm{IFI}<0.95$ & .931 \\
\hline TLI & TLI $\geq 0.95$ & $0.90<\mathrm{TLI}<0.94$ & .923
\end{tabular}




\subsection{Reliability Analysis of the Scale}

The Cronbach's alpha reliability coefficient for the Sustainable Development Awareness Scale developed by the researchers was calculated for the whole scale and the sub-dimensions.

Reliability analysis of the scale was conducted with SPSS 15 package program. As a result of the analysis made, the reliability coefficient for the whole scale was calculated as Cronbach's $\alpha=0.91$. The reliability coefficients for the sub-dimensions were Cronbach's $\alpha=0,77$ for the economy sub-dimension, Cronbach's $\alpha=0,87$ for the society sub-dimension, and Cronbach's $\alpha=0,82$ for the environment sub-dimension (Table 2).

When the reliability coefficient values calculated for the scale developed by the researchers to be used as data collection tool are examined, it is seen that a Cronbach's alpha value of .70 and above are sufficient as it is in this case (Acar, Kara, \& Taşkın Ekici, 2015; Artvinli \& Demir, 2018; Büyüköztürk, 2017).

Table 2. Reliability Coefficients of the Whole Scale and the Sub-dimensions of the Scale

\begin{tabular}{lc}
\hline Dimensions & Cronbach's Alpha Reliability Coefficient \\
\hline Economy sub-dimension & 0,77 \\
Society sub-dimension & 0,87 \\
Environment sub-dimension & 0,82 \\
\hline Whole Scale & 0,91 \\
\hline
\end{tabular}

Following the validity and reliability studies, the final form of the Sustainable Development Awareness Scale consists of 36 items with three sub-dimensions: economy, society, and environment. Items $1,2,3,4,5,6,7,8,9,10,11,12$, and 13 of the scale belong to the economic sustainability sub-dimension. While the items 14, 15, 16, 17, 18, 19, 20, 21, and 22 belong to the sub-dimension of social sustainability, the items $23,24,25,27,28,29,30,31,32,33,34$, 35,36 , and 37 belong to the environmental sustainability sub-dimension. Items 1, 8, 10, 24, 31 , and 35 are negative and the item 26 is control. The lowest score to be taken from the scale was calculated as 36 and the highest score as 180 (Appendix 1).

\section{CONCLUSION}

It is of great importance that the sustainable development awareness occurs in countries where industrialization and urbanization continue rapidly. With this scale developed, it is aimed to determine the awareness of science teacher candidates, who are responsible for ensuring sustainable development awareness in society, before they begin to the profession. For this reason, this study has been carried out with the aim of developing a valid and reliable measurement tool to determine the awareness of science teacher candidates about sustainable development. The Sustainable Development Awareness Scale developed in this study has three sub-dimensions as economy, society, and environment in accordance with the theoretical framework accepted in the literature. The sub-dimensions of the 36-item Sustainable Development Awareness Scale were supported using confirmatory factor analysis. Findings obtained after the analyses support the fact that the developed scale is a suitable measurement tool for determining the sustainable development awareness of science teacher candidates.

The fact that item number of the scale developed in this study is more compared to the previous scales increased the content validity of the scale. There are 14 items that measure the environmental sub-dimension of the scale, 13 items that measure the economy sub-dimension, and 9 items that measure the social sub-dimension. These items reflect the features of these sub-dimensions in a more detailed and comprehensive way than previously developed scales. 
While this scale is being developed, the economic, social, and environmental sub-dimensions were designed to be independent of each other. When the items fell into the intersection areas of these three dimensions, it has been decided by experts which dimension the item should be included. As a recommendation to the researchers who want to develop a sustainable development awareness scale in the next stage, a seven sub-dimensional scale may be proposed, which considers the intersection areas of sub-dimensions as separate sub-dimensions. This scale was developed for science teacher candidates. However, it is expected that they will give similar results when working with science teachers. It may also be recommended to carry out studies of reliability and validity by applying the scale to science teachers.

\section{Acknowledgment}

The English version of this scale is in the end of this article. However, the English version is not suitable to use because its language validity has not been analyzed. The English version of the scale is just for the readers' curiosity.

This study has been derived from the first author's master thesis.

\section{ORCID}

\section{Seyit Ahmet Kiray (D) https://orcid.org/0000-0002-5736-2331}

\section{REFERENCES}

Acar, C., Kara, I., \& Taşkın Ekici, F. (2015). Development of Self Directed Learning Skills Scale for Pre-Service Science Teachers. International Journal of Assessment Tools in Education, 2(2), 3-13.

Akcay, B., Gelen, B., Tiryaki, A., \& Benek, I. (2018). An analysis of scale adaptation studies in science education: Meta-synthesis study. Journal of Education in Science, Environment and Health (JESEH), 4(2), 227-245. DOI:10.21891/jeseh.439150

Alkış, S. (2007). Coğrafya eğitiminde yükselen paradigma: Sürdürülebilir bir dünya. [The rising paradigm in teaching geography: a sustainable world] Marmara Coğrafya Dergisi, 15, 55-64.

Altunbaş, D. (2003). Uluslararası sürdürüebilir kalkınma ekseninde Türkiye'deki kurumsal değişimlere bir bakış. [A new perspective towards the institutional changes in Turkey within the frame of international sustainable development] Yönetim Bilimleri Dergisi, 1(1-2), 103-118.

Artvinli, E., \& Demir, Z. M. (2018). A study of developing an environmental attitude scale for primary school students. Journal of Education in Science, Environment and Health (JESEH), 4(1), 32-45. DOI:10.21891/jeseh.387478

Atmaca, A.C., Kiray, S.A., \& Pehlivan, M. (2018). Sustainable Development from Past to Present. In Shelley, M. \& Kiray, S.A.(Ed.). Education Research Highlights in Mathematics, Science and Technology 2018 (pp. 186-214). ISRES Publishing, ISBN: 978-605-81654-3-4. https://www.isres.org/education-research-highlights-inmathematics-science-and-technology-2018-6-b.html\#.XCPdZ1wzZPY

Aydoğan, A. (2010). Sosyal bilgiler ögrretmenlerinin sürdürülebilir kalkınma konusuyla ilgili kazanımların ögretimine ilişkin görüşleri. [Social studies teachers' views on the teaching of achievements related to sustainable development] Yüksek Lisans Tezi. Niğde Üniversitesi Sosyal Bilimler Enstitüsü İlköğretim Anabilim Dalı, Niğde.

Baykal, H., \& Baykal, T. (2008). Küreselleşen dünyada çevre sorunları. [Environmental problems in a globalized world] Mustafa Kemal Üniversitesi Sosyal Bilimler Enstitüsü Dergisi, 5(9). 
Biasutti, M., \& Surian, A. (2012). The students' survey of education for sustainable development competencies: A comparison among faculties. Discourse and Communation for Sustainable Development, 3(1), 75-82.

Biasutti, M., \& Frate, S. (2017). A validity and reliability study of the attitudes toward sustainable development scale. Environmental Education Research, 23(2), 214-230.

Borg, C., Gericke, N., Höglund, H. O., \& Bergman, E. (2012). The barriers encountered by teachers implementing education for sustainable development: Discipline bound differences and teaching traditions. Research in Science \& Technological Education, $30(2), 185-207$.

Büyüköztürk, Ş. (2017). Sosyal bilimler için very analizi el kitabı [The data analysis manual for the social sciences] (23. Bask1). Ankara. Pegem Akademi.

Chow, W. S., \& Chen, Y. (2012). Corporate sustainable development: Testing a new scale based on the Mainland Chinese context. Journal of Business Ethic, 105(4), 519-533.

Demirbaş, Ç. Ö. (2015). Öğretmen adaylarının sürdürülebilir kalkınma farkındalık düzeyleri. [Sustainable development awareness levels of teacher candidates.] Marmara Coğrafya Dergisi, 31, 300-3016.

DeVellis, R.F. (2012). Scale development: Theory and applications. Sage Publications, Thousand Oaks, CA.

Doğan, O., Bulut, Z. A., \& Çımrın, F. K. (2015). Bireylerin sürdürülebilir tüketim davranışlarının ölçülmesine yönelik bir ölçek geliştirme çalışması. [A scale development study to measure individuals' sustainable consumption behavior] İktisadi ve Idari Bilimler Dergisi, 29(4), 659-678.

Erten, S. (2015). Sample course material for biodiversity and sustainable education. International Journal of Education in Mathematics, Science and Technology, 3(2), 155161.

Hebebci, M.T., \& Shelley, M. (2018). International Journal of Assessment Tools in Education, 5(2), 223-234.

Kahyaoğlu, M. (2011). Öğretmen adaylarının öğrenme stilleri ile çevre eğitimi öz-yeterlilikleri arasındaki ilişki.[Relationship between the Self Efficacy Beliefs towards Environmental Education and the Learning Styles of Pre-service Teachers] Eğitim Bilimleri Araştırmaları Dergisi, 1(2), 68-82.

Kaya, M. F. (2013). Sürdürülebilir kalkınmaya yönelik tutum ölçeği geliştirme çalışması. [A Scale development study on the attitudes of sustainable development] Marmara Cografya Dergisi, 28, 175-193.

Koçak, F., \& Balcı, V. (2010). Doğada yapılan sportif etkinliklerde çevresel sürdürülebilirlik. [The environmental sustainability in the sporting events in nature ] Ankara Üniversitesi Çevre Bilimleri Dergisi, 2(2), 213-222.

Kuşat, N. (2013). Yeşil sürdürülebilirlik için yeşil ekonomi: Avantaj ve dezavantajları Türkiye incelemesi. [Green economy for green sustainability: advantages and disadvantages turkey review] Journal of Yasar University, 29(8), 4896-4916.

Kline, R. B. (2005). Principles and practice of structural equation modeling (2nd ed.). New York: Guilford Press.

Manju, N. D. (2015). A study on opinion of teachers about role of education in sustainable development. International Journal of Education and Psychological Research, 4(1), 6064.

Olsson, D., Gericke, N., \& Chang Rundgren, S. N. (2016). The effect of implementation of education for sustainable development in Swedish compulsory schools: Assessing pupils' sustainability consciousness. Environmental Education Research, 22(2), 176-202. 
Özmete, E., \& Akgül Gök, F. (2015). Sürdürülebilir kalkınma için sosyal inovasyon ve sosyal hizmet ilişkisinin değerlendirilmesi.[Evaluation of relationship between social inovation and social work for sustainable development] Hacettepe Üniversitesi İktisadi ve İdari Bilimler Fakültesi Sosyal Hizmet Bölümü Dergisi, 26(2), 127-143.

Sandel, K., Öhman, J., \& Östman, L. (2006). Education for sustainable development: Nature, school and democracy. Lund: Student literattur.

Summers, M., Kruger, C., Childs, A., \& Mant, J. (2010). Primary school teachers' understanding of environmental issues: An interview study. Environmental Education Research, 6(4), 294-312.

Şahin, İ., \& Kutlu, S. Z. (2014). Cittaslow: Sürdürülebilir kalkınma ekseninde bir değerlendirme. [Cittaslow: an assessment from the perspective of sustainable development] Journal of Tourism and Gastronomy Studies, 2(1), 55-63.

Tabachnick, B. G., \& Fidell, L. S. (2007). Experimental designs using ANOVA. Thomson/Brooks/Cole

Türer, B. (2010). Fen bilgisi ve sosyal bilgiler ögretmen adaylarının sürdürülebilir kalkınma farkindallklarinın belirlenmesi.[The awarness levels of science and social science prospective teachers regarding sustainable environment] Yüksek Lisans Tezi. Ondokuz Mayıs Üniversitesi, Eğitim Bilimleri Enstitüsü, İlköğretim Anabilim Dalı, Samsun.

United Nations. (1987). Report of the world commission on environment and development: Our common future. http://www.un-documents.net/our-common-future.pdf (Reached on 02.12.2017).

UNESCO. (2006). United Nations decade of education for sustainable development 20052014, UNESCO: International implementation scheme. Paris: UNESCO.

WCED. (1987). Our common future: A report from the United Nations World Commission on Environment and Development. Oxford: Oxford University Press.

Yerdelen, S., Cansiz, M., Cansiz, N., \& Akcay, H. (2018). Promoting preservice teachers' attitudes toward socioscientific issues. Journal of Education in Science, Environment and Health (JESEH), 4(1), 1- 11. DOI:10.21891/jeseh.387465 
Appendix 1. Sustainable Development Awareness Scale Items (English version)

\begin{tabular}{ll}
\hline & Items \\
\hline 1 & Individuals should shop in the direction of their desires and wishes without regard to their needs. \\
\hline 2 & We must use current economic resources with conservation, thinking about future generations. \\
\hline 3 & Debt to be made for development should be made considering economic balances. \\
\hline 4 & Economic policies should be able to reduce poverty and differences in income distribution. \\
\hline 5 & Economic development should be planned to prevent unemployment. \\
\hline 6 & Economic policies should be shaped by sustainable production. \\
\hline 7 & Economic policies should be shaped so as not to destroy natural resources. \\
\hline 8 & $\begin{array}{l}\text { Livestock, agricultural and industrial production should be focused on applications that will generate } \\
\text { high profits in the short term (use of GMO products, hormonal animals etc.). }\end{array}$ \\
\hline 9 & $\begin{array}{l}\text { For economic investments, environments where life and property safety are provided must be } \\
\text { established. }\end{array}$ \\
\hline 10 & For economic development, non-production sectors should be emphasized. \\
\hline 11 & The production of high-tech products for economic development should be supported. \\
\hline 12 & Investments in agriculture and livestock sectors should be supported for economic development. \\
\hline 13 & Research and development (R\&D) studies for economic development should be supported. \\
\hline 14 & \begin{tabular}{l} 
Equal opportunities should be offered to individuals in society (women/men, rich/poor, race/religion \\
\hline
\end{tabular}
\end{tabular}
etc.).

15 For all individuals in society, environments should be created to enable the individual to learn lifelong.

16 Individuals should be provided with integrating and enhancing social services (such as nurseries, shelter homes, social assistance foundations etc.).

$17 \quad$ Access to education and health services should be provided to all individuals in society.

18 Individuals should be provided with environments where they feel safe while living.

19 Interaction of cultures in society should be supported and developed.

20 The society must take responsibility to keep the well-being of individuals and families above the minimum.

21 Urbanization (city, town, etc.) should be to protect the soul and body health of the society.

22 The work of governmental and non-governmental organizations involved in activities for the sustainable environment should be supported.

23 Any intervention that damages natural life (wrong use of pesticide, prohibited hunting, etc.) must be punished for the continuation of biological diversity.

24 The use of public transportation at short distances does not help to maintain atmospheric equilibrium.

$25 \quad$ I think that vehicles with the least impact on degradation of ecological balance should be preferred when buying one.

$26 \quad$ Energy saving products should be preferred in order to use energy sources for a longer time.

27 The use of renewable energy sources needs to be widespread to leave a livable world.

28 Every individual has responsibility to protect existing resources (water, air, soil etc.) for future generations to survive ecological problems.

$29 \quad$ Industrial establishments should take cautions to protect environmental health and prevent pollution of natural resources.

$30 \quad$ Green areas can be dispensed with for urbanization and industrialization.

31 In order to leave a greener world for future generations, responsibility for afforestation and the protection of the trees is the responsibility of each individual.

32 I think that each individual has responsibilities in the process of recycling wastes so that the raw material resources can be used by future generations.

33 Wastes should be separated according to their characteristics and reused, so that raw material sources can be used by future generations.

$34 \quad$ I think that nothing can be done individually to prevent global climate change.

35 I think global warming poses a serious threat to the future of our world if cautions are not taken.

36 I think that ecological footprint should be minimized for the continuation of the world's livability. 
Appendix 2. Sustainable Development Awareness Scale Items (Turkish version)

Maddeler

$1 \quad$ Bireyler ihtiyaçlarını gözetmeksizin, arzu ve istekleri doğrultusunda alış veriş yapmalıdır.

2 Gelecek nesilleri de düşünerek mevcut ekonomik kaynakları tasarruflu kullanmalıyız.

3 Kalkınma için yapılacak borçlanma ekonomik dengeler gözetilerek yapılmalıdır.

$4 \quad$ Ekonomik politikalar, yoksulluğu ve gelir dağılımındaki farklılıkları azaltıcı nitelikte olmalıdır.

$5 \quad$ Ekonomik kalkınma işsizliği önleyecek şekilde planlanmalıdır.

$6 \quad$ Ekonomik politikalar sürdürülebilir üretime göre şekillenmelidir.

7 Ekonomik politikalar doğal kaynakları yok etmeyecek şekilde oluşturulmalıdır.

$8 \quad$ Hayvancılık da, tarımsal ve endüstriyel üretim de, kısa vadede yüksek kâr elde edecek uygulamalara (GDO' lu ürün kullanımı, hormonlu hayvanlar v.b.) ağırlık verilmelidir.

$9 \quad$ Ekonomik yatırımlar için can ve mal güvenliğinin sağlandığı ortamlar oluşturulmalıdır.

10 Ekonomik kalkınma için üretim dışı sektörlere ağırlık verilmelidir.

11 Ekonomik kalkınma için ileri teknoloji ürünlerinin üretimi desteklenmelidir.

12 Ekonomik kalkınma için tarım ve hayvancılık sektörlerine yapılacak yatırımlar desteklenmelidir.

13 Ekonomik kalkınma için araştırma geliştirme (AR-GE) çalışmaları desteklenmelidir.

14 Toplumdaki bireylere (kadın/erkek, zengin/fakir, ırk/din v.b.) eşit fırsatlar sunulmalıdır.

15 Toplumdaki bütün bireyler için bireyin yaşam boyu öğrenmesine olanak sağlayacak ortamlar oluşturulmalıdır.

16 Bireylere, toplumla bütünleştirici ve geliştirici sosyal hizmetler (çocuk yuvaları, huzur evi, sosyal yardımlaşma vakıfları v.b.) sunulmalıdır.

17 Toplumdaki bütün bireylere eğitim ve sağlık hizmetlerine ulaşım hakkı sağlanmalıdır.

18 Bireylere, yaşadıkları yerlerde kendilerini güvende hissedecekleri bir ortam oluşturulmalıdır.

19 Toplumda ki kültürlerin birbiri ile etkileşimi desteklenmeli ve geliştirilmelidir.

20 Bireylerin ve ailelerin refah düzeyini asgari koşulların üzerinde tutmak için toplum sorumluluk almalıdır.

21 Şehirleşme, (şehir, kasaba v.b) toplumun ruh ve beden sağlığını koruyacak şekilde olmalıdır.

22 Sürdürülebilir çevre için faaliyetlerde bulunan resmi ve sivil toplum kuruluşlarının çalışmaları desteklenmelidir.

23 Biyolojik çeşitliliğin devamı için doğal yaşama zarar veren her müdahale (bilinçsiz ilaçlama, yasak avlanma vb.) cezalandırılmalıdır.

24 Kısa mesafelerde toplu taşıma araçları kullanılmasının atmosferik dengenin korunmasına faydası yoktur.

25 Araç alırken, ekolojik dengenin bozulmasına etkisi en az olan araçların tercih edilmesi gerektiğini düşünüyorum.

26 Enerji kaynaklarının daha uzun süreli kullanılabilmesi için enerji tasarrufu yapan ürünlerin tercih edilmesi gerekir.

27 Yaşanılabilir bir dünya bırakabilmek için yenilenebilir enerji kaynaklarının kullanımının yaygınlaştırılması gerekir.

28 Gelecek nesillerin ekolojik sorunlar yaşamaması için mevcut kaynakların (su, hava, toprak v.b.) korunması hususunda her bireye düşen sorumluluklar vardır.

29 Endüstri kuruluşları çevre sağlı̆̆ını koruyacak ve doğal kaynakların kirletilmesini önleyecek tedbirler almalidir.

$30 \quad$ Yeşil alanlardan şehirleşme ve sanayileşme amacıyla vazgeçilebilir.

31 Gelecek nesillere daha yeşil bir dünya bırakabilmek için ağaçlandırma çalışmaları ve ağaçların korunması ile ilgili her bireye sorumluluk düşmektedir.

32 Ham madde kaynaklarının gelecek nesiller tarafından da kullanılabilmesi için atıkların geri dönüştürülmesi sürecinde her bireyin sorumlulukları olduğunu düşünüyorum.

33 Ham madde kaynaklarının gelecek nesiller tarafından da kullanılabilmesi için çöpler özelliklerine göre ayrilarak, değerlendirilmelidir.

34 Küresel iklim değişikliğini önlemek için bireysel olarak hiçbir şey yapılamayacağını düşünüyorum.

35 Önlem alınmaması halinde küresel ısınmanın, dünyamızın geleceği için ciddi tehdit oluşturduğunu düşünüyorum.

36 Dünyanın yaşanılabilirliğinin devamı için ekolojik ayak izimizin küçültülmesi gerektiğini düşünüyorum. 